\title{
Effectiveness of topical antibiotics in treating corals affected by Stony Coral Tissue Loss Disease
}

\author{
Karen L Neely ${ }^{\text {Corresp., } 1}$, Kevin A Macaulay ${ }^{1}$, Emily K Hower ${ }^{1}$, Michelle A Dobler ${ }^{1}$ \\ ${ }^{1}$ Halmos College of Natural Sciences and Oceanography, Nova Southeastern University, Fort Lauderdale, FL, United States \\ Corresponding Author: Karen L Neely \\ Email address: kneely0@nova.edu
}

Since 2014, Stony Coral Tissue Loss Disease (SCTLD) has led to mass mortality of the majority of hard coral species on the Florida Reef Tract. Following the successful treatment of SCTLD lesions on laboratory corals using water dosed with antibiotics, two topical pastes were developed as vehicles to directly apply antibiotic treatments to wild corals. These pastes were tested as placebos and with additions of amoxicillin on active SCTLD lesions on multiple coral species. The effectiveness of the pastes without antibiotics (placebo treatments) was less than $10 \%$, no different from untreated controls. Adding amoxicillin to both pastes significantly increased effectiveness to $70 \%$ and $84 \%$. Effectiveness with this method was seen across five different coral species, with success rates of the more effective paste ranging from $67 \%$ (Colpophyllia natans) to $90 \%$ (Orbicella faveolata and Montastraea cavernosa). Topical antibiotic application is a viable and effective tool for halting disease lesions on corals affected by SCTLD. 
1 Effectiveness of topical antibiotics in treating corals affected by Stony Coral Tissue Loss

2 Disease

3

4 Karen L. Neely ${ }^{1}$, Kevin A. Macaulay ${ }^{1}$, Emily K. Hower ${ }^{1}$, Michelle A. Dobler ${ }^{1}$

$5 \quad{ }^{1}$ Nova Southeastern University Halmos College of Natural Sciences and Oceanography, Fort

6 Lauderdale, FL 33314, USA

7

8 Corresponding Author:

9 Karen L. Neely 1

10 Nova Southeastern University Halmos College of Natural Sciences and Oceanography, Fort

11 Lauderdale, FL 33314, USA

12 Email address: kneely0@nova.edu 


\section{Abstract}

Since 2014, Stony Coral Tissue Loss Disease (SCTLD) has led to mass mortality of the majority of hard coral species on the Florida Reef Tract. Following the successful treatment of SCTLD lesions on laboratory corals using water dosed with antibiotics, two topical pastes were developed as vehicles to directly apply antibiotic treatments to wild corals. These pastes were tested as placebos and with additions of amoxicillin on active SCTLD lesions on multiple coral species. The effectiveness of the pastes without antibiotics (placebo treatments) was less than $10 \%$, no different from untreated controls. Adding amoxicillin to both pastes significantly increased effectiveness to $70 \%$ and $84 \%$. Effectiveness with this method was seen across five different coral species, with success rates of the more effective paste ranging from $67 \%$ (Colpophyllia natans) to 90\% (Orbicella faveolata and Montastraea cavernosa). Topical antibiotic application is a viable and effective tool for halting disease lesions on corals affected by SCTLD.

\section{Introduction}

Beginning in 2014, a disease since named Stony Coral Tissue Loss Disease (SCTLD) appeared on scleractinian corals near Miami, Florida (Precht et al. 2016). It has since spread throughout the Florida Reef tract with a spatial pattern following a contagious model of transmission (Muller et al. 2020). Beginning in 2017, SCTLD began appearing in other regions of the Caribbean (Alvarez-Filip et al. 2019; Weil et al. 2019). The disease is known to affect over 20 species of corals and is characterized by multifocal acute lesions that in some cases are preceded by a bleaching margin (FKNMS/DEP 2018). It is highly virulent, and capable of being transmitted by physical contact and also through seawater (Aeby et al. 2019). Progression of lesions across a colony is rapid compared to most other coral diseases, and in the majority of cases, lesions result in complete colony mortality. Ecosystem impacts are substantial and include significant decreases in coral cover, colony density, and biodiversity (Precht et al. 2016; Walton et al. 2018).

Fulfillment of Koch's postulates for coral diseases is particularly difficult (Richardson 1998) and definitive pathogen identification for SCTLD has not been successful. However, efforts to identify the cause of the epidemic are ongoing and have identified differences in bacterial 
42 communities between healthy and diseased corals (Meyer et al. 2019; Rosales et al. 2020).

43 Additionally, early laboratory work noted that water dosing with antibiotics resulted in disease cessation (O'Neil et al. 2018; Aeby et al. 2019), suggesting a bacterial component. Though both amoxicillin and ampicillin water baths were effective, ampicillin was preferred as it dissolved more easily. Follow up efforts by NOAA's Coral Disease and Health Consortium (C Woodley, pers comm) developed a modified dental paste that could be applied to disease margins; this product is still in use by laboratories and aquariums treating SCTLD-affected corals (O'Neil et al. 2018). However, the use of the modified dental paste requires patting the coral dry and maintaining it in low water flow for 18 hours, making it impracticable on wild corals. To resolve this, partnerships between the authors, the Florida Aquarium, and a pharmaceutical formulation and manufacturing company (Ocean Alchemists LLC and CoreRx Pharmaceuticals) led to the development of topical pastes that could be used in field applications to determine whether SCTLD could be stopped on in situ colonies with active lesions.

This study compared the effectiveness of untreated controls, two placebo topical pastes (here termed Base $2 \mathrm{~b}$ and New Base), and both pastes with amoxicillin additives to determine whether disease lesions could be halted.

\section{Materials \& Methods}

Corals affected with Stony Coral Tissue Loss Disease were selected for treatment at Sand Key (Fig. 1) in the lower Florida Keys (permit from Florida Keys National Marine Sanctuary \#2019115). Colonies were located within a $4000 \mathrm{~m}^{2}$ area ranging in depth from 5 to 13 meters.

A total of 61 corals representing five species were selected for experimental treatment in October 2019. Each colony had between 1 and 12 active SCTLD lesions, and a total of 171 lesions were treated (Table 1). Due to the limited availability of suitable colonies and the varying number of lesions on each, the numbers of colonies and lesions were not the same across species and treatments. Three species (Colpophyllia natans, Montastraea cavernosa, Orbicella faveolata) were represented across all treatments. $C$. natans has been identified as a highly susceptible species, while $M$. cavernosa and $O$. faveolata have been classed as intermediately susceptible 
species (FKNMS/DEP 2018). Two additional highly susceptible species, Diploria labyrinthiformes and Pseudodiploria strigosa, were compared between just two treatment types.

Selected colonies all had visibly active and rapidly progressing SCTLD disease lesions as identified by at least $1 \mathrm{~cm}$ of bright white bare skeleton adjacent to live tissue. Colonies had maximum linear dimensions ranging from 12 to $432 \mathrm{~cm}$. Each colony was tagged and mapped for future identification. A masonry nail (2") was hammered into each lesion to identify the location and progression of the disease margin.

Colonies were randomly assigned one of five treatments.

1. Control. Colony was tagged and nails were affixed at the disease margin, but no treatment was applied.

2. "Base $2 \mathrm{~b}$ " Placebo. A proprietary (CoreRx/Ocean Alchemists) silicone-based paste that included polymers to mimic coral mucus consistency was applied directly to the disease $\operatorname{margin}(\mathrm{s})$.

3. Base $2 b+$ Amoxicillin. The silicone-based paste was hand mixed with powdered amoxicillin (sourced from Phytotechnology Laboratories. 98.1\% purity) in an 8:1 (base:amoxicillin) by weight ratio. The paste included time-release products that regulate release of the amoxicillin over a three-day time period.

4. "New Base" Placebo. A proprietary (CoreRx/Ocean Alchemists) biodegradable hydrophobic ointment designed to hold and release antibacterial compounds.

5. New Base + Amoxicillin. The New Base Placebo was mixed with powdered amoxicillin in an 8:1 by weight ratio. Release modifiers in the base facilitated amoxicillin release over three days.

Treatments were prepared less than 6 hours before application by mixing amoxicillin into treatments 3 and 5 , and by packing treatments $2-5$ into $60 \mathrm{cc}$ catheter syringes. At each affected coral, a treatment was squeezed from the syringe and pressed by hand onto the length of the disease margin in a band approximately $1 \mathrm{~cm}$ wide. Half $(0.5 \mathrm{~cm})$ of the application overlaid and anchored on to the dead skeleton while $0.5 \mathrm{~cm}$ covered adjacent live tissue. If there were multiple lesions on a coral, they all received the same treatment. The amount of treatment product applied to each coral varied with the number and the size of lesions but averaged 12.3 
99

100

101

102

103

104

105

106

107

108

109

110

111

112

113

114

115

116

117

118

119

120

121

122

123

124

125

126

$\mathrm{mL}( \pm 11.2 \mathrm{~mL} \mathrm{SD})$ per treated coral. Among the 28 amoxicillin-treated colonies, an average of $1.6 \mathrm{~g}( \pm 1.7 \mathrm{~g} \mathrm{SD})$ of amoxicillin was applied for a total application of 39.6 grams at the site.

Corals were monitored four weeks after the initial treatment. At each coral, the number of effective and ineffective treatments were tallied. Photographs were also taken and arranged so before and after photos of each lesion could be compared (representative samples: Fig. 2). All analyses were based on the photographic comparisons because more lesions could be positively identified. Effectiveness was defined as the cessation of disease progression at the treatment line. Ineffectiveness was defined as the lesion continuing unimpeded across the colony. After the onemonth monitoring, all lesions on all surviving corals were treated with Base $2 b+$ Amoxicillin. A total of 55 retreated lesions ( 5 C. natans, 19 M. cavernosa, and 31 O. faveolata) were reassessed two months later for effectiveness.

The proportion of halted lesions were compared across treatments using Fisher's exact test $(\alpha=0.05)$, which is suitable for unequal as well as small sample sizes. Lesions on the same coral were considered independent because:

1. Microbiome studies of SCTLD colonies identify healthy regions of tissue adjacent to diseased regions (Meyer et al. 2019)

2. Field observations of lesion development on individual colonies over time note asynchronous appearance, suggesting independent development.

Additional analyses that do not assume lesion independence were conducted by comparing the proportion of halted lesions on each colony across species and treatments. Sample sizes were small, (between one and six colonies per species per treatment), unequal, and failed normality tests (Kolmogorov-Smirnov), so One-Way ANOVA on Rank tests were used to compare treatments.

\section{Results}

The percentage of effective lesion treatments varied by treatment type and, to some extent, species (Fig. 3). Across all species, 0\% of the control (untreated) lesions halted. Overall effectiveness of New Base Placebo and Base 2b Placebo treatments on lesions were 4\% (1/27) 
127 and 9\% (4/47) respectively. When amoxicillin was added, effectiveness increased to 70\% (16/23)

128 for the New Base and 84\% (49/58) for the Base $2 b$.

129 Because the treatments varied in the number of lesions on different species, analyses were

130 further broken down by species (Table 2). Colpophyllia natans treatments showed the least

131 difference between placebo and amoxicillin treatments; when amoxicillin was added to both the

132 New Base and the Base 2b, effectiveness increased by 29\%. On Orbicella faveolata,

133 effectiveness increased $78 \%$ when amoxicillin was added to the New Base and 91\% when added

134 to the Base 2b. On Montastraea cavernosa, the addition of amoxicillin increased effectiveness

135 by $100 \%$ in New Base and $89 \%$ in Base 2 b as compared to their placebo counterparts. Because of

136 species rarity, Diploria labyrinthiformes and Pseudodiploria strigosa lesions treatments were

137 restricted to Base $2 b$ Placebo and Base $2 b+$ Amoxicillin treatments; effectiveness was $0 \%$ with

138 placebo treatments, while 88\% (7/8: D. labyrinthiformes) and 73\% (11/15: P. strigosa) of

139 amoxicillin treated lesions were effective.

140 Fisher's exact tests identified similarities and differences among treatments (Table 2). On $O$.

141 faveolata, M. cavernosa, and C. natans, there were no significant differences between untreated

142 controls, New Base Placebo, and Base 2b Placebo. On C. natans, there were no significant

143 differences between any treatments (controls, placebos, and non-placebos), although the p-value

144 between untreated controls and Base $2 \mathrm{~b}+$ Amoxicillin was 0.055. On both O. faveolata and $M$.

145 cavernosa, there were significant differences between controls and both amoxicillin products.

146 There were also significant differences between both placebo bases and their amoxicillin

147 counterparts. There were no significant differences in effectiveness between New Base +

148 Amoxicillin and Base 2b + Amoxicillin. On D. labyrinthiformes and P. strigosa, effectiveness of

149 Base $2 b+$ Amoxicillin was significantly higher than the Base $2 b$ Placebo $(p=0.001)$. Across

150 five of the six tested species, the percentage of lesions halted using both amoxicillin bases was

151 between 73\% - 90\%. However, amoxicillin treatments on Colpophyllia natans were less

152 effective, particularly with the New Base (29\%).

153 Treatments were also analyzed at a colony level in consideration that host genotype may play a

154 role in treatment effectiveness. The percentage of halted lesions on each colony was compared 155 across treatments for each species (Fig. 4). For all species, the percentage of halted lesions was

156 higher for New Base + Amoxicillin or Base $2 b+$ Amoxicillin treatments than for placebo-treated 
157 colonies and controls. Statistically, ANOVA on Rank tests across all treatment types had

158 extremely low power and could not detect post-hoc differences between treatments by species

159 (Table 3). However, individual ANOVA on Rank tests did detect significant differences on $P$.

160 strigosa between Base $2 \mathrm{~b}+$ Amoxicillin and Base $2 \mathrm{~b}$ Placebo $(\mathrm{p}=0.038)$, and also on $O$.

161 faveolata between Base $2 \mathrm{~b}+$ Amoxicillin compared to both Base 2b Placebo and New Base

162 Placebo ( $\mathrm{p}=0.008$ and $<0.001$ respectively).

163 One month after treatment, one of the control colonies and six of the Base $2 \mathrm{~b}$ Placebo colonies

164 had died completely. Of the surviving colonies, new lesions had developed on: $40 \%$ of the

165 controls, $50 \%$ of the New Base placebo, 29\% of the Base 2 b placebo, 29\% of the New Base +

166 Amoxicillin, and 33\% of the Base $2 b+$ Amoxicillin. Failed and new lesions from all surviving

167 colonies were treated with Base $2 b+$ Amoxicillin. Fifty-five of those retreatments were re-

168 surveyed after two months; $80 \%$ of $C$. natans lesions, $77 \%$ of $O$. faveolata lesions, and $58 \%$ of

169 M. cavernosa lesions had halted.

\section{Discussion}

172 Past uses of antibiotics on diseased corals have included utilization as a diagnostic tool to help

173 identify bacteria as a presumptive pathogen in white band disease (Kline and Vollmer 2011;

174 Sweet et al. 2014) as well as water dosing to halt SCTLD lesion progression in laboratory and

175 aquarium work (C Woodley, K O’Neil, C Lewis, pers comm). The use of skin wound treatment

176 patches containing antiseptics, antioxidants, and/or antibiotics have also shown promise in

177 helping mechanically damaged corals to heal (Contardi et al. 2020). However, the results

178 presented here represent the first known use of topical antibiotics as a disease treatment tool to

179 preserve wild populations. Effectiveness of placebos was no greater than for untreated controls,

180 but the addition of amoxicillin significantly increased the percentage of lesions halted.

181 Antibiotic application was successful at halting lesions on all tested species, but effectiveness on

182 C. natans was lower, particularly for the New Base + Amoxicillin treatment. We suggest that the

183 deep polyp grooves of $C$. natans create gaps where the treatment is not in contact with coral

184 tissue. Divers noted that the New Base had poorer adherence to the coral colonies than the Base

1852 b, which may have been particularly pronounced in the highly rugose C. natans, thus creating 
186 ineffective treatment barriers. Careful application into grooves to ensure physical contact with

187 the coral tissue is suggested.

188 Antibiotic effectiveness is likely to remain localized within the region of application rather than

189 spreading throughout the colony; this is evidenced by the appearance of new lesions on some

190 amoxicillin-treated corals. To minimize mortality, coral colonies require one-month revisitation

191 in order to retreat any failed margins and to treat any new lesions. Longer-term studies are

192 recommended and currently underway to determine appropriate visitation intervals and long-

193 term maintenance requirements. Physiological studies determining the spread of the amoxicillin

194 throughout the colony and the mechanism for effectiveness are also recommended.

195 Treatment of SCTLD-affected colonies using topical amoxicillin paste is an option for SCTLD

196 disease intervention. The methodology has already been utilized to save laboratory and aquaria

197 corals (Florida Aquarium, Keys Marine Lab, Frost Museum of Science), offshore nursery corals

198 (Coral Restoration Foundation and Florida Keys National Marine Sanctuary), corals targeted for 199 assisted reproduction efforts (Mote Marine Lab), and the preservation of over 2000 large reef-

200 building corals on the Florida Reef Tract (Nova Southeastern University, Harbor Branch

201 Oceanographic Institute). Such actions have been and should continue to be weighed in a risk

202 management scenario that considers unknown factors such as impacts on the treated corals'

203 microbiomes as well as potential antibiotic resistance. Though requiring an investment of time

204 and resources for initial treatment as well as repeated visitation, topical antibiotic treatment is a 205 viable tool for preserving high-value corals.

\section{Conclusions}

208 Topical amoxicillin treatments successfully arrested disease lesion progression on multiple species of stony corals affected by Stony Coral Tissue Loss Disease. As this disease spreads throughout already affected reefs as well as new regions of the Caribbean, this type of in-water intervention is an option to be considered within management response strategies. Follow-up studies on the physiological mechanisms, potential risks, and long-term trajectory of treated

213 corals are recommended. 
215

216

217

218

219

220

221

222

223

224

225

226

227

228

229

230

231

232

233

234

235

236

237

238

239

240

241

242

243

244

245

246

247

248

249

250

251

252

253

254

255

256

\section{Acknowledgements}

Work was conducted in the Florida Keys National Marine Sanctuary under permit FKNMS2019-115. Use of antibiotics was approved by the US Food and Drug Administration's Office of Minor Use and Minor Species. We are grateful to the editor and three reviewers for improvements to this manuscript.

\section{Literature Cited}

Aeby G, Ushijima B, Campbell JE, Jones S, Williams G, Meyer JL, Hase C, Paul V (2019) Pathogenesis of a tissue loss disease affecting multiple species of corals along the Florida Reef Tract. Frontiers in Marine Science 6

Alvarez-Filip L, Estrada-Saldívar N, Pérez-Cervantes E, Molina-Hernández A, González-Barrios FJ (2019) A rapid spread of the stony coral tissue loss disease outbreak in the Mexican Caribbean. PeerJ 7:e8069

Contardi M, Montano S, Liguori G, Heredia-Guerrero JA, Galli P, Athanassiou A, Bayer IS (2020) Treatment of Coral Wounds by Combining an Antiseptic Bilayer Film and an Injectable Antioxidant Biopolymer. Scientific Reports 10:988

FKNMS/DEP (2018) Case Definition: Stony Coral Tissue Loss Disease, https://floridadep.gov/sites/default/files/Copy\%20of\%20StonyCoralTissueLossDisease CaseDefinition\%20final\%2010022018.pdf

Kline D, Vollmer SV (2011) White Band Disease (type I) of Endangered Caribbean Acroporid Corals is Caused by Pathogenic Bacteria

Meyer JL, Castellanos-Gell J, Aeby GS, Häse CC, Ushijima B, Paul VJ (2019) Microbial Community Shifts Associated With the Ongoing Stony Coral Tissue Loss Disease Outbreak on the Florida Reef Tract. Frontiers in Microbiology 10

Muller EM, Sartor C, Alcaraz NI, van Woesik R (2020) Spatial Epidemiology of the StonyCoral-Tissue-Loss Disease in Florida. Frontiers in Marine Science 7:163

O'Neil K, Neely KL, Patterson J (2018) Nursery management and treatment of disease-ravaged pillar coral (Dendrogyra cylindrus) on the Florida Reef Tract. Florida DEP, Miami, FL 113

Precht WF, Gintert BE, Robbart ML, Fura R, van Woesik R (2016) Unprecedented DiseaseRelated Coral Mortality in Southeastern Florida. Scientific Reports 6

Richardson LL (1998) Coral diseases: what is really known? Trends Ecol Evol 13:438-443

Rosales SM, Clark AS, Huebner LK, Ruzicka RR, Muller E (2020) Rhodobacterales and Rhizobiales are associated with Stony Coral Tissue Loss Disease and its suspected sources of transmission. Frontiers in Microbiology 11:681

Sweet MJ, Croquer A, Bythell JC (2014) Experimental antibiotic treatment identifies potential pathogens of white band disease in the endangered Caribbean coral Acropora cervicornis. Proceedings of the Royal Society B-Biological Sciences 281

Walton CJ, Hayes NK, Gilliam DS (2018) Impacts of a Regional, Multi-Year, Multi-Species Coral Disease Outbreak in Southeast Florida. Frontiers in Marine Science 5

Weil E, Hernández-Delgado E, Gonzalez M, Williams S, Suleimán-Ramos S, Figuerola M, Metz-Estrella T (2019) Spread of the new coral disease "SCTLD" into the Caribbean: implications for Puerto Rico. Reef Encounter 34:38-43 


\section{Figure Legends}

259 Figure 1. Map showing research site (star) at Sand Key, Florida Keys. Grey indicates land, pink represents patch reefs, and red indicates spur and groove reefs.

Figure 2. Representative photos of placebo (progressing) treatments and amoxicillin (halted) treatments. Species codes are: PSTR - Pseudodiploria strigosa, DLAB - Diploria labyrinthiformes, OFAV - Orbicella faveolata. Photos show the corals immediately before treatment was applied, immediately after treatment was applied, and one month after treatment. The exception is the " 1 month" photo of the placebo DLAB $\left(^{*}\right)$, which was taken two weeks after treatment; the colony was totally dead at one month.

Figure 3. Number of halted (A) and progressing (B) lesions one month after treatments. Colors represent different species. Total percentage of lesions that halted under each treatment regime are shown above the halted lesion bars.

Figure 4. The average percentage of lesion treatments that were halted on each coral colony, separated by species and treatment type. Error bars indicate standard error. 
Figure 1

Map of research site at Sand Key, Florida Keys

Figure 1. Map showing research site (star) at Sand Key, Florida Keys. Grey indicates land, pink represents patch reefs, and red indicates spur and groove reefs.

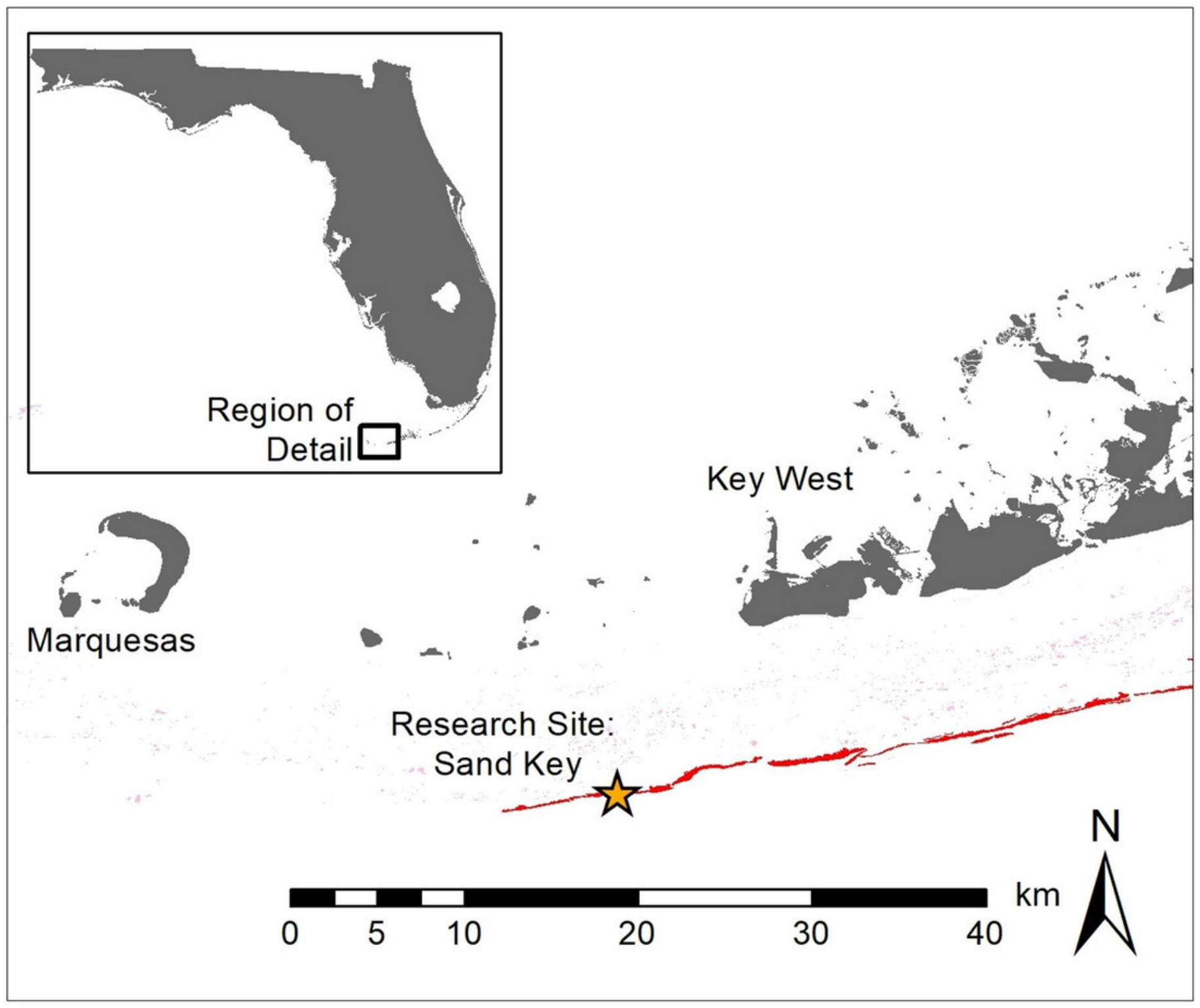




\section{Figure 2}

Representative photos of placebo and amoxicillin-treated SCTLD lesions

Figure 2. Representative photos of placebo (progressing) treatments and amoxicillin (halted) treatments. Species codes are: PSTR - Pseudodiploria strigosa, DLAB - Diploria labyrinthiformes, OFAV - Orbicella faveolata. Photos show the corals immediately before treatment was applied, immediately after treatment was applied, and one month after treatment. The exception is the "1 month" photo of the placebo DLAB $(*)$, which was taken two weeks after treatment; the colony was totally dead at one month. 


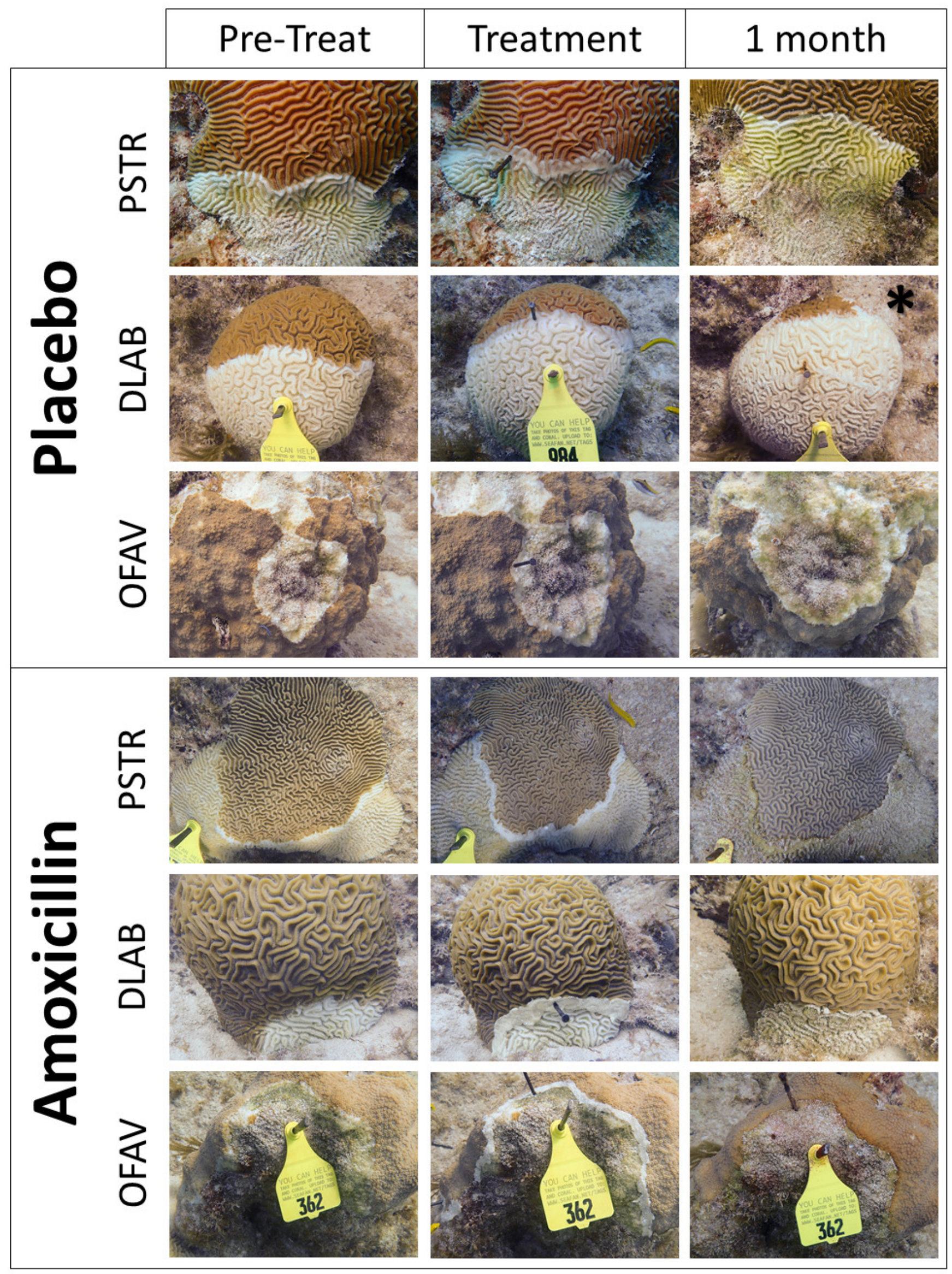


Figure 3

Number of halted and progressing lesions for each treatment type

Figure 3. Number of halted (A) and progressing (B) lesions one month after treatments.

Colors/patterns represent different species. Total percentage of lesions that halted under each treatment regime are shown above the halted lesion bars. 


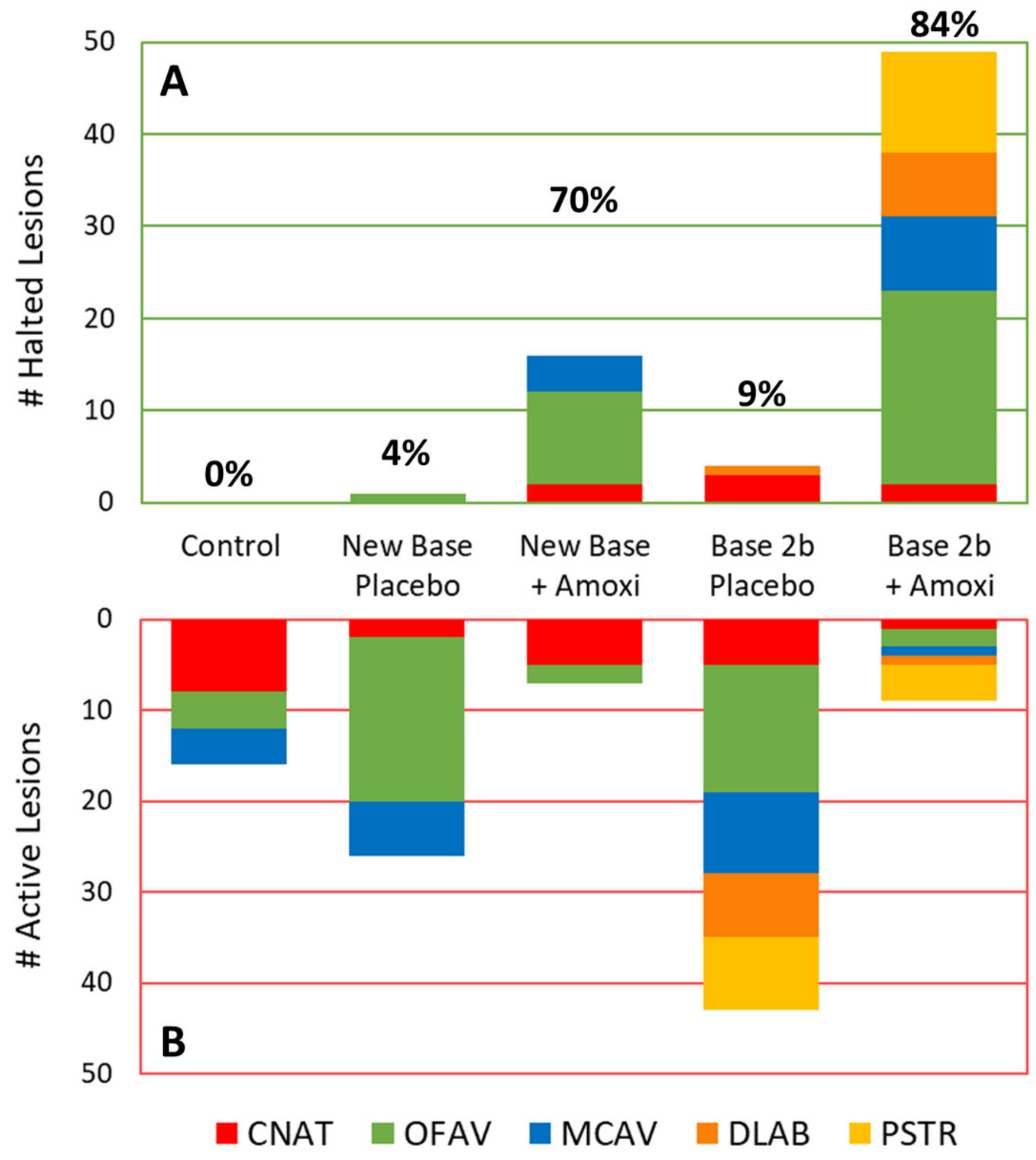


Figure 4

Percentage of effective lesion treatments per colony

Figure 4 . The average percentage of lesion treatments that were effective on each coral colony, separated by species and treatment type. Error bars indicate standard error.

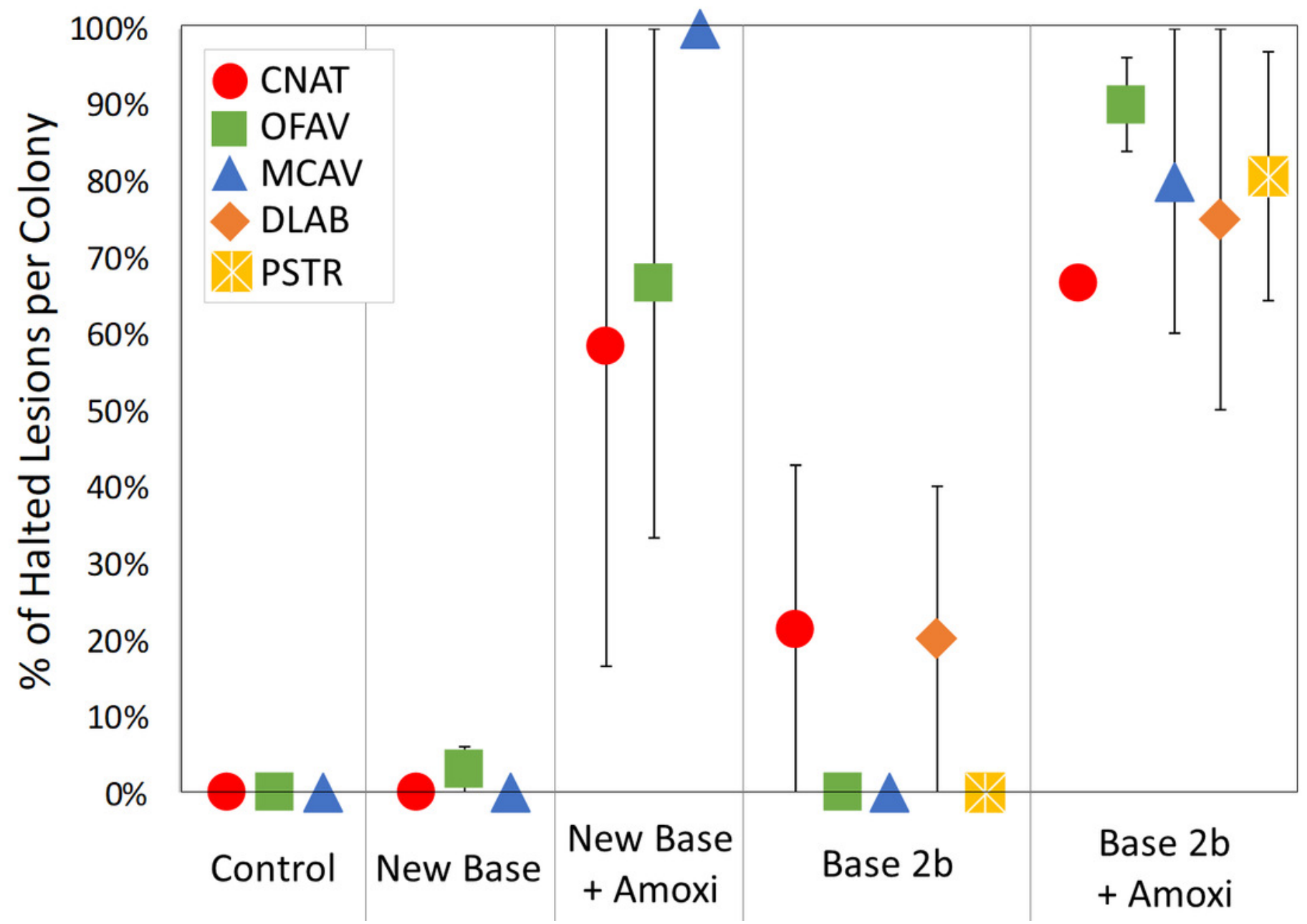




\section{Table $\mathbf{1}$ (on next page)}

Number of colonies and lesions receiving each treatment.

Table 1. Number of colonies (top) and lesions (bottom) receiving each treatment ("Amoxi" represents addition of powdered amoxicillin). Four-letter species codes represent: Colpophyllia natans (CNAT), Montastraea cavernosa (MCAV), Orbicella faveolata (OFAV), Diploria labyrinthiformes (DLAB), and Pseudodiploria strigosa (PSTR). 
1 Table 1. Number of colonies (A) and lesions (B) receiving each treatment ("Amoxi" represents

2 addition of powdered amoxicillin). Four-letter species codes represent: Colpophyllia natans

3 (CNAT), Montastraea cavernosa (MCAV), Orbicella faveolata (OFAV), Diploria

4 labyrinthiformes (DLAB), and Pseudodiploria strigosa (PSTR).

\begin{tabular}{|c|c|c|c|c|c|c|}
\hline A & & Control & $\begin{array}{c}\text { New Base } \\
\text { Placebo }\end{array}$ & $\begin{array}{c}\text { New Base }+ \\
\text { Amoxi }\end{array}$ & $\begin{array}{l}\text { Base } 2 b \\
\text { Placebo }\end{array}$ & $\begin{array}{c}\text { Base } 2 b+ \\
\text { Amoxi }\end{array}$ \\
\hline \multirow{5}{*}{ 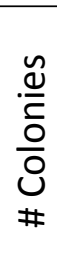 } & CNAT & 2 & 2 & 2 & 2 & 1 \\
\hline & MCAV & 2 & 3 & 2 & 3 & 5 \\
\hline & OFAV & 2 & 3 & 3 & 5 & 5 \\
\hline & DLAB & & & & 5 & 4 \\
\hline & PSTR & & & & 4 & 6 \\
\hline
\end{tabular}

B

\begin{tabular}{|c|c|c|c|c|c|c|}
\hline \multirow{5}{*}{$\begin{array}{l}\stackrel{n}{c} \\
.0 \\
\text { d } \\
\#\end{array}$} & CNAT & 8 & 2 & 7 & 8 & 3 \\
\hline & MCAV & 4 & 6 & 4 & 9 & 9 \\
\hline & OFAV & 4 & 19 & 12 & 14 & 23 \\
\hline & DLAB & & & & 8 & 8 \\
\hline & PSTR & & & & 8 & 15 \\
\hline
\end{tabular}

5 


\section{Table 2 (on next page)}

Number of effective and ineffective lesion treatments with statistical comparisons.

Table 2. Number of effective and ineffective lesion treatments for each species and treatment type (first row of each species) and p-values from Fisher's exact test comparisons between treatments for each species (comparison matrix). Statistically significant results are highlighted in green. 
Table 2. Number of effective and ineffective lesion treatments for each species and treatment type (first row of each species) and pvalues from Fisher's exact test comparisons between treatments for each species (comparison matrix). Statistically significant results 3 are highlighted in green.

\begin{tabular}{|c|c|c|c|c|c|}
\hline A - CNAT & Control & $\begin{array}{c}\text { New Base } \\
\text { Placebo }\end{array}$ & $\begin{array}{c}\text { New Base }+ \\
\text { Amoxi }\end{array}$ & Base 2b Placebo & Base 2b + Amoxi \\
\hline Effective:Ineffective & $0: 8(0 \%)$ & $0: 2(0 \%)$ & $2: 5(29 \%)$ & $3: 5(38 \%)$ & $2: 1(67 \%)$ \\
\hline \multicolumn{7}{|l|}{} \\
\hline Control & & N/A (both zero) & 0.2 & 0.2 & 0.055 \\
\hline New Base & N/A (both zero) & & 1 & 1 & 0.4 \\
\hline New Base + Amoxi & 0.2 & 1 & 1 & 1 & 0.5 \\
\hline B2B & 0.2 & 1 & 1 & & 0.54 \\
\hline B2B + Amoxi & 0.055 & 0.4 & 0.5 & 0.54 & \\
\hline
\end{tabular}

\begin{tabular}{|c|c|c|c|c|c|}
\hline B - OFAV & Control & $\begin{array}{c}\text { New Base } \\
\text { Placebo }\end{array}$ & $\begin{array}{c}\text { New Base }+ \\
\text { Amoxi }\end{array}$ & Base 2b Placebo & Base 2b + Amoxi \\
\hline Effective:Ineffective & $0: 4(0 \%)$ & $1: 18(5 \%)$ & $10: 2(83 \%)$ & $0: 14(0 \%)$ & $21: 2(91 \%)$ \\
\hline \multicolumn{7}{|l|}{} \\
\hline Control & & 1 & 0.008 & N/A (both zero) & $<0.001$ \\
\hline New Base & 1 & & $<0.001$ & 1 & $<0.001$ \\
\hline New Base + Amoxi & 0.008 & $<0.001$ & & $<0.001$ & 0.594 \\
\hline B2B & N/A (both zero) & 1 & $<0.001$ & & $<0.001$ \\
\hline B2B + Amoxi & $<0.001$ & $<0.001$ & 0.594 & $<0.001$ & \\
\hline
\end{tabular}

\begin{tabular}{|l|c|c|c|c|c|}
\hline C - MCAV & Control & $\begin{array}{c}\text { New Base } \\
\text { Placebo }\end{array}$ & $\begin{array}{c}\text { New Base }+ \\
\text { Amoxi }\end{array}$ & Base 2b Placebo & Base 2b + Amoxi \\
\hline Effective:Ineffective & $0: 4(0 \%)$ & $0: 6(0 \%)$ & $4: 0(100 \%)$ & $0: 9(0 \%)$ & $8: 1(89 \%)$ \\
\hline \multicolumn{6}{|l|}{} \\
\hline Control & N/A (both zero) & N/A (both zero) & 0.029 & N/A (both zero) & 0.007 \\
\hline New Base & N/A (both zero) & 0.001 \\
\hline
\end{tabular}




\begin{tabular}{|c|c|c|c|c|c|} 
New Base + Amoxi & 0.029 & 0.005 & & 0.001 & 1 \\
\hline B2B & N/A (both zero) & N/A (both zero) & 0.001 & & $<0.001$ \\
\hline B2B + Amoxi & 0.007 & 0.001 & 1 & $<0.001$ & \\
\hline
\end{tabular}

\begin{tabular}{|c|c|c|c|}
\hline \multicolumn{2}{|l|}{$D$ - DLAB } & Base $2 \mathrm{~b}$ Placebo & Base $2 b+$ Amoxi \\
\hline Effective:Ineffective & $p=0.001$ & 1:7 (13\%) & 7:1 (88\%) \\
\hline
\end{tabular}

\begin{tabular}{|l|c|c|c|}
\hline \multicolumn{2}{|l|}{ E - PSTR } & Base 2b Placebo & Base 2b + Amoxi \\
\cline { 4 - 5 } Effective:Ineffective & $p=0.001$ & $0: 8(0 \%)$ & $11: 4(73 \%)$ \\
\hline
\end{tabular}




\section{Table 3(on next page)}

Percentage of effective lesions on corals, with statistical comparisons.

Table 3. Average percentage ( \pm standard error) of effective lesions on corals, separated by species and treatment (first row of each species), and p-values from One-Way ANOVA on Ranks comparing treatments (comparison matrix). Statistically significant results are highlighted in green. 
1 Table 3. Average percentage ( \pm standard error) of effective lesions on corals, separated by species and treatment (first row of each 2 species), and p-values from One-Way ANOVA on Ranks comparing treatments (comparison matrix). Statistically significant results 3 are highlighted in green.

4

\begin{tabular}{|c|c|c|c|c|c|}
\hline A - CNAT & Control & $\begin{array}{c}\text { New Base } \\
\text { Placebo }\end{array}$ & $\begin{array}{c}\text { New Base }+ \\
\text { Amoxi }\end{array}$ & Base 2b Placebo & Base 2b + Amoxi \\
\hline Average \% ( \pm SE) & $0 \pm 0$ & $0 \pm 0$ & $58 \pm 42$ & $21 \pm 21$ & $67 \pm N / A$ \\
\hline \multicolumn{7}{|l|}{} & 1 & & 0.667 & N/A \\
\hline Control & 1 & & 0.333 & 0.667 & N/A \\
\hline New Base & 0.333 & 0.333 & & 0.667 & N/A \\
\hline New Base + Amoxi & 0.667 & 0.667 & 0.667 & & N/A \\
\hline B2B & N/A & N/A & N/A & N/A & \\
\hline B2B + Amoxi & & & & & \\
\hline
\end{tabular}

\begin{tabular}{|c|c|c|c|c|c|}
\hline B - OFAV & Control & $\begin{array}{c}\text { New Base } \\
\text { Placebo }\end{array}$ & $\begin{array}{c}\text { New Base }+ \\
\text { Amoxi }\end{array}$ & Base 2b Placebo & Base 2b + Amoxi \\
\hline Average \% \pm SE) & $0 \pm 0$ & $3 \pm 3$ & $67 \pm 33$ & $0 \pm 0$ & $90 \pm 6$ \\
\hline \multicolumn{7}{|l|}{} & 0.495 & 0.136 & 1 & 0.095 \\
\hline Control & & & 0.24 & 0.57 & $<0.001$ \\
\hline New Base & 0.495 & 0.24 & & 0.143 & 0.399 \\
\hline New Base + Amoxi & 0.136 & 0.57 & 0.143 & & 0.009 \\
\hline B2B & 1 & $<0.001$ & 0.399 & 0.009 & \\
\hline
\end{tabular}

\begin{tabular}{|l|c|c|c|c|c|}
\hline C - MCAV & Control & $\begin{array}{c}\text { New Base } \\
\text { Placebo }\end{array}$ & $\begin{array}{c}\text { New Base }+ \\
\text { Amoxi }\end{array}$ & Base 2b Placebo & Base 2b + Amoxi \\
\hline Average \% ( \pm SE) & $0 \pm 0$ & $0 \pm 0$ & $100 \pm 0$ & $0 \pm 0$ & $80 \pm 20$ \\
\hline
\end{tabular}




\begin{tabular}{|c|c|c|c|c|c|}
\hline Control & & 1 & 0.333 & 1 & 0.19 \\
\hline New Base & 1 & & 0.33 & 1 & 0.19 \\
\hline New Base + Amoxi & 0.333 & 0.33 & & 0.2 & 0.857 \\
\hline B2B & 1 & 1 & 0.2 & & 0.07 \\
\hline B2B + Amoxi & 0.19 & 0.19 & 0.857 & 0.07 & \\
\hline
\end{tabular}

\begin{tabular}{|l|c|c|c|}
\hline D - DLAB & $p=0.27$ & Base 2b Placebo & Base 2b + Amoxi \\
\cline { 3 - 5 } & Average $\%( \pm$ SE) & $20 \pm 20$ & $75 \pm 25$ \\
\hline
\end{tabular}

\begin{tabular}{|l|c|c|c|}
\hline E - PSTR & Base 2b Placebo & Base 2b + Amoxi \\
\cline { 4 - 5 } Average $\%( \pm$ SE) & $p=0.03$ & $0 \pm 0$ & $81 \pm 16$ \\
\hline
\end{tabular}

